\title{
An Overview of Developments and Trends in Modern and Contemporary Chinese Literature
}

\author{
Adrian A. Lindsay \\ School of Literature, Northeast Normal University, Renmin Street No. 5268, Changchun City, Jilin \\ Province, People's Republic of China
}

\begin{abstract}
This paper analyses the development of Chinese modern and contemporary literary trends and phenomena from the perspectives of modernity and postmodernism and gives readers a comprehensive understanding of modern and contemporary Chinese literature. The author traces the origin of the expression "Chinese modern and contemporary literature" and summarizes the important aspects of the revolution of Chinese literature which have led to the creation of modern and contemporary Chinese literature. In this paper, the author examines the influence of great Western thinkers such as Freud, Nietzsche, Heidegger, and Sartre who have made outstanding and lasting contributions to the development and reform of modern Chinese literature in different literary circles. In addition, the author highlights some of the prominent literary themes that permeate Chinese modern literature and discusses the changes in the attitude of literary scholars to different literary genres. This paper also discusses the popular trends of modern Chinese literature and the development trend of postmodern literature.
\end{abstract}

Keywords: modernity, modern and contemporary literature, Chinese literature, literary trends, literary genres

DOI: $10.7176 / J L L L / 62-08$

Publication date: November $30^{\text {th }} 2019$

\section{Modernity and Chinese Literature}

Modern Chinese literature may be defined by scholars from different perspectives, but it is of utmost importance that it is understood within the context of the Chinese view of modernity, which takes into consideration the social, cultural, economic and historical conditions of the late nineteenth century and early twentieth century. Eisenstadt (2000) gives a suitable definition for modernity from the perspective of the proponents of the term "Multiple Modernities" which refers to a certain view of the contemporary world that goes against the views that were previously prevalent in scholarly and general discourse. The idea of "multiple modernities" presumes that the best way to understand the contemporary is to see it as a story of continual constitution and reconstitution of a multiplicity of cultural programs. One of the most important implications of the term "multiple modernities" is that modernity and Westernization are not identical, while Western patterns of modernity are not the only "authentic" modernities, though they enjoy historical precedence and continue to be a basic reference point for others. Interestingly, there has been a constant renewal of the way in which the term "modernity" was originally understood where it was based on historical, cultural, political and social patterns of the West. Wang (2009) asserts that modernity does not only refer to the new and innovative especially because, from a cultural perspective, the "modernness" of the May Fourth period was influenced by Western ideas of science, democracy, liberty, equality, individualism, etc., while these ideologies were influenced by Chinese intellectuals' perception of a modern wold. Additionally, these intellectuals sought to accomplish modernity by establishing new social, economic, political and cultural institutions in an effort to restructure the nation at all levels in society.

It is important to note that modern Chinese literature should also be understood in its relations with classical traditions as well as its relations with new Western form of literary expressions. In China, in the late 1800s, there was a movement by intellectuals to advocate for a change from the literary structures of the Qing dynasty to "something new". Zhang (2016) defines "new" as "tempering with what one originally has to make it new; and to take what one did not have and acquire it as new." This, he argues, indicates that the desired newness at that time would "arise from the social and cultural environment that necessarily contained the old, which was either to be changed or to be eliminated." The introduction of the theory of modernity has opened up a new area for the study of literary trends of thoughts as scholars have begun to grasp the characteristics of the whole 20th century Chinese literary trends of thoughts from the macro perspective of modernity. Lin (2006), in her article on the trends of modernity and 20th century Chinese literature, refers to three main principles of modern Chinese literature that are based on three motives of the 20th Century Chinese Literary Revolution: literary modernity, political modernity and economic modernity. These theories, perspectives and concepts of modernity provide a new paradigm for the study of Chinese literary trends of thoughts in the 20th century because they are conducive to the clarification of the complex relationship between various literary trends or their evolution or coexistence, and then give a new historical description of Chinese literature in the 20th century. 


\section{The Emergence of the Concept of Modern and Contemporary Chinese Literature}

According to Zhu (2016), the term "Modern and Contemporary Chinese Literature" suggests that, in addition to Mandarin, Chinese literature should cover literature in languages of other ethnic groups in China and should comprise literary writings in the traditional Chinese languages and traditional Chinese literary genres. While pioneers such as Lu Xun, Hu Shi, Zhou Zuoren and Mao Dun advocated for new literature and new culture, especially during the May Forth period, several literary phenomena emerged such as movements, activities, controversies, schools and trends. Zhu believes that democracy and science were two strong points of the May 4th New Literature Movement and New Cultural Movement. He claims that the democratic trend constitutes the core spirit of New Literature in Chinese and it is nearly a reflection of all factors that represent modern ideas, while science was seen as a disharmonious factor in the construction of New Literature.

It is believed that writers such as $\mathrm{Hu}$ Shi and $\mathrm{Lu}$ Xun among others started using the term New Literature as they conducted research in that field. However, due to the requirement of a political expression, the body of New Literature in Chinese was called "Modern Chinese Literature". Not long after, the term "Contemporary Chinese Literature" emerged which seemed to be more comprehensive and represented a new era in terms of ideology and literature, even though the term "Modern Chinese Literature" had a clearer denotation and connotation in terms of definition. As a result, academic administrative bureaus and literary researchers united in coining the new term "Modern and Contemporary Chinese Literature".

\section{The Revolution of Chinese Literature}

According to Mcdougall and Louie (1997), twentieth-century Chinese literature can be divided into three major periods on the basis of changes within the structure of the literary canon. The first period, from 1900 to 1937 , represents the beginning of a distinctively new literature in China which was largely influenced by the West. The second period, from 1938 to 1965 , can be seen as a period of diversion from the new Westernized form of literature because of the impact of the Japanese invasion and the need for writers to be more responsive to native Chinese traditions in order to reach a wider audience. The third period, from 1966 to 1976, was the period of the Cultural Revolution in China during which the control of the Communist party and the influence of the Soviet model were undermined, bringing an end to the second period.

The Literary Revolution originally addressed replacing the classical language with the living language of the people as a medium for written communication. During this period, Hu Shi, one of the most important Chinese intellectuals of the 20th century and influential post-imperial thinker and writer in China, advocated a literature that should be characterized by the embodiment of true feelings and concrete thoughts with an emphasis on grammar and a readiness to use colloquial words and expressions. According to Li (1959), in his article "Continuity and Change in Modern Chinese Literature", Chen Duxiu, one of the founders of the Chinese Communist Party and a major leader in developing the cultural basis of revolution in China, supported Hu Shi's ideas in an essay in which he revealed the following slogans:

1. To destroy the painted, powdered and obsequious literature of the aristocratic few, and to create a plain, simple, and expressive literature of the people.

2. To destroy the stereotyped and monotonous literature of classism, and to create a fresh and sincere literature of realism.

3. To destroy the pedantic, unintelligible, and obscurantist literature of the hermit and the recluse, and to create a plain-speaking and popular literature of a living society.

The strong influence of Western literary works on Chinese literature, especially in the May 4th period, led to a break from the native literary traditions. Even though there were writers who opposed the literary reform, there were many Chinese writers who denounced their traditional forms of literature and sought after a completely new form of literature. However, despite the literary reform, traditional Chinese literature retained its value and eminence.

\section{The Influence of Western Philosophers}

The beginning of the $20^{\text {th }}$ century is marked as a significant period in the development and evolution of modern and contemporary Chinese literature. This was deemed a turbulent time in China when the country was experiencing political, economic, social and literary reforms, and major events such as May 4th Movement, Women's Liberation Movement, and The China's Cultural Revolution that took place in the twentieth century led to the emergence of a new form of literature in China. However, the effects of these movements on Chinese literature were largely due to heavy influence from Western literary concepts, style and language. According to Bonnie S. Mcdougall and Kam Louie (1997), the literary works produced during and after these periods adopted modern literary traditions and further Westernization, and even created an environment for experimentation while setting the tone for a new era in 
contemporary Chinese literature. Therefore, during this period, prevalent Western thinkers such as Freud, Nietzsche, Heidegger, and Sartre were able to make outstanding and lasting contributions to the development and reform of Chinese modern literature in different literary circles.

As an influential Western thinker, Freud also had a strong influence on contemporary Chinese literature, especially from the period of the May 4th Movement to the 1930s. However, after 1949, due to political and ideological reasons, Freudianism became dormant in China. Wang (1993) claims that upon close observation of writers' propensity for sexual psychoanalysis and sexual description in their writings, it is presumed that Freudianism has been misused in Chinese literary circles. He believes that the aim of Freudianism was not to encourage writers to indulge in excess sexual descriptions, but to encourage the exploration of scientific and theoretical basis on which writers could detect the unconscious mind. This influence made Chinese writers able to describe the contents of the characters subconscious and unconscious thoughts. Freud also influenced Chinese literature in the area of reconsidering and rewriting the history of modern Chinese literature and the teaching of the literature of this period at undergraduate and graduate levels. However, Freud's influence subsided in the 1990s because of various social, political, economic, historical, cultural and aesthetic factors.

Other Western thinkers and philosophers such as Nietzsche, Martin Heidegger and Sartre made significant contributions to the development of modern and contemporary Chinese literature. Nietzsche was an important Western thinker who had a great influence on twentieth century Chinese literature even though, in the end, he was seen by many scholars as just a writer rather than a philosopher or thinker. As for Martin Heidegger, many Chinese writers, mostly form philosophical and critical circles, developed an interest in his ideologies. However, his works were difficult to understand, so ordinary writers and critics gave up studying his ideas, even though they were important to the Chinese debate on modernism and postmodernism. Chinese writers were also influenced by Sartre and his existentialist philosophy even though it was too abstract and difficult for them as well. Nevertheless, his philosophies had a close relation with social reality, political ideology, and literary creation which made his influence prevail for a long period of time. It is evident that great Western thinkers such as Freud, Nietzsche, Martin Heidegger and Sartre have all left an indelible mark on the Chinese literary scene as they have undoubtedly influenced the works of many writer of modern and contemporary China.

\section{Literary Genres and Dominant Themes}

According to Mcdougall and Louie (1997), through intensive debates of the 1910s and 1920s, "literature" became understood as a body of written work comprising of a set of genres - chiefly fiction, poetry and drama - in which individual expression through consciously employed artistic techniques became characteristic mode. Wang and Sun (2008) claim that the four major literary genres in Chinese literature, namely the novel, new poetry, drama and the essay were strongly inspired by Western literature. However, the most significant influence is that on the Chinese language, and subsequently on the very nature of modern Chinese literature.

Modern Chinese literature consists mainly of published fiction, drama and poetry, with occasional special cases of manuscript or oral form, while traditionally, Chinese literature can be divided into two groups according to the language in which it was written: the classical literature (poetry and essays) which were written in a highly developed literary language characterized by compressed syntax and an elaborate, allusive vocabulary; and the oral literature of folksong and opera in stylized regional forms. In Modern Chinese literature, fiction has been the most popular mode of expression in the 20th century. Due to the increasing importance of fiction on the literary scene, scholars advocated for the inclusion of fiction in the literary canon and allowing of the use of the vernacular in poetry and prose. This idea was faced with a short-lived opposition as the traditional vernacular language was transformed into a new vernacular language which combined elements of Western vocabulary and grammar with contemporary and colloquial forms.

Poetry has always been a dominant form of expression in traditional societies like China. However, according to Wang and Sun (2008), the introduction of the new vernacular in poetry negatively impacted the respectability of poetry. There is classical poetry which many people enjoy and folk poetry which includes oral compositions and performances in both cities and the countryside. There are also modern Chinese poems called "new poetry", which usually do not follow any prescribed pattern. Early 20th-century poets like Xu Zhimo, Guo Moruo and Wen Yiduo sought to break Chinese poetry from past conventions by adopting Western models.

Another popular literary genre is drama which takes the form of plays with a written text for spoken performances on stage. Traditional Chinese drama comprises a wide diversity of theatrical forms in cities, towns and villages, in which the main characteristics are singing (not much recitation), musical accompaniment, elaborate costuming, stylized gestures, dance and acrobatics. However, twentieth century reforms to Chinese drama made it more similar to the written play of the contemporary Western form, which includes the use of scripted, colloquial prose dialogue and socially reformist or morally sensitive themes. The five-act plays of the 1930 s were considered most successful $20^{\text {th }}$ 
century Chinese drama because of the combined traditional staging with the sensationalism of Western plots and interspersed contemporary dialogue with Western or Chinese style music or song.

As it relates to themes in modern Chinese literature, Zhang (2016) indicates that the "tension and connection between the city and the countryside constitute one of the major themes in modern Chinese literature". Therefore, one may conclude that modern Chinese literature is predominantly outlined and defined by rural and regional themes because most of the Chinese population was peasants and farmers during that period. Additionally, Wardega (2009) highlights other dominant themes in modern Chinese literature which include: "a value system in constant change; a longing for stability amid uncertainties about the future; and a new consciousness about the unlimited challenges and aspirations in modern life."

Western literary theories and concepts significantly contributed to the revolutionary change in scholars' approach to literary genres, especially fiction and drama. The literary scholars at that time believed that the purpose of fiction and drama was just for entertainment and that they had no didactic value. However, after the literary revolution in China, fiction and drama became highly regarded genres in Chinese literature while poetry continues to experience newness while retaining its traditional substance.

\section{Prevalent Trends of Modern and Contemporary Chinese Literature}

The dominant trends of Modern and Contemporary Chinese Literature covers topics related to postmodernism and postmodern criticism and maintains a focus on cultural studies and historical hermeneutics. According to Wang (2012), "postmodernism first emerged in architecture as an international, cultural and intellectual movement, and subsequently emerged in literature and other forms of art and culture." China's move to hold a high regard in the study of world literature in the 20th century led to the emergence of international postmodernist movements which provided contemporary Chinese literature with an opportunity to take part in dialogues with other world literatures. Wang further claims that there was also the existence of an elite culture among the literary scholars which has been challenged by the following post-modern tendencies:

1. The radical experimentation of avant-garde writers who questioned the humanistic spirit of the new period, causing the literature and elite culture to become more and more formalistic and technique oriented.

2. The rise and continuous development of a new realist fiction which represents a strong reaction to the experimentation of avant-gardists as well as a sort of transcendence over the traditional realistic aesthetic principle.

3. The contemporary commercialization of Chinese fiction, which is intended to bridge the gap between elite and popular literature.

In terms of the relationship between cultural studies and literary studies, Wang posits that the advent of cultural studies (the study of contemporary culture), which grew out of theoretical debates and discussions held in literary circles and then in other fields, posed a challenge to literature in post-revolutionary China because many Chinese literary scholars changed their research interests to cultural studies. However, while China seemed to be moving towards a socialist market economy and prepares to enter a post-revolutionary period, there were scholars who persisted in exploring cultural theory and its value in academic circles with the aim of possibly constructing a Chinese cultural theory.

It is believed that modern China is characterised by historical catastrophes which caused traumatic experiences that writers have used to underscore their literary writings. With this approach, authors analyse how literary expressions articulate in order to attain a certain degree of historical depth in their works. In this way, authors can help readers understand how different texts represent history and give insights on how history can be textualized and visualized. Wang (2009) believes that exploring historical hermeneutics means inquiring "why and how different class consciousness and historical conditions circumscribed writers to recognise the political situation and propelled them to carry out their aesthetic ideal, leaving traceable signatures and imprints in their works to be deciphered."

In the current context of Chinese literature and culture, there are ongoing discussions on the topic of modernity and its relation to postmodernism and globalization, while entertaining the idea of the possibility of constructing a Chinese cultural theory. With regards to historical hermeneutics in modern Chinese literature, the semiotic system of literary text can be broken down to show history and politics and may lead to appropriately contextualizing the internal structure of aesthetic texts, explaining the most idiosyncratic aesthetic detail.

\section{Conclusion}

Changes continue to take place in the Chinese literary world as new concepts of modernity continue to emerge. Chinese writers unceasingly explore foreign literary styles and a wide variety of themes that were once taboo. As a result, writers now enjoy a new level of freedom in expressing their thoughts and ideas about different aspects of the Chinese society in more unconventional ways as they explore both traditional and non-traditional themes. Even though 
Western literature and philosophies have had a great influence on modern and contemporary Chinese literature, great care is taken by many scholars to maintain Chinese traditional literary forms. Finally, the term "Modern and Contemporary Chinese literature" is relatively broad and may be able to sustain both current and future changes in the field of Chinese literature.

\section{References}

Bonnie S. McDougall and Kam Louie. (1997) The Literature of China in the Twentieth Century. Hong Kong: University Press, p. 8.

Eisenstadt, S. N. (2000). 'Multiple Modernities', Daedalus, Vol. 129, No. 1, pp. 1-29. Retrieved from www.jstor.org/stable/20027613

Li, Tien-yi. (1959). Continuity and Change in Modern Chinese Literature. The Annals of the American Academy of Political and Social Science, Vol. 321, pp. 90-99. Retrieved from www.jstor.org/stable/1030983 林朝霞. (2006). 现 代性与 20 世纪中国文学思潮研究述评. 厦门: 厦门大学报（哲学社会出版社）, pp. 19-25.

(Translation: Lin, Zhaoxia (2006). A Research Review of Modernity and the Trend of Chinese Literature in the 20th Century. Xiamen: Xiamen University Journal (Philosophy and Social Publishing House), pp. 19-25.)

Wang, Ning. (2012). Chinese Literary and Cultural Trends in a Postrevolutionary Era. Comparative Literature Studies, Vol. 49, No. 4, pp. 505-520. Retrieved from www.jstor.org/stable/10.5325/complitstudies.49.4.0505

Wang, Ning. (1993). Confronting Western Influence: Rethinking Chinese Literature of the New Period. New Literary History, Vol. 24, No. 4, pp. 905-926. Retrieved from www.jstor.org/stable/469400

Wang, Ning and Sun, Yifeng. (2008). Translation, Globalisation and Localisation: A Chinese Perspective. UK: Multilingual Matters Ltd., p. 65.

Wardega, Artur K. (2009). Belief, History and the Individual in Modern Chinese Literary Culture. UK: Cambridge Scholars Publishing.

Zhang, Yingjin (2016). A Companion to Modern Chinese Literature. UK: John Wiley \& Sons Ltd, pp. 41-44.

Adrian A. Lindsay is currently pursuing a PhD in Modern and Contemporary Chinese Literature in the School of Literature at Northeast Normal University, China. While his main area of research is in the field of Chinese Literature, his extended areas of research include Chinese-English translation and teaching Chinese as a foreign language. 